\title{
Analysis of the Propagation Effects of Remittances on the Vulnerability of External Trade of the Republic of Moldova
}

\section{Mircea DIAVOR}

\begin{abstract}
In the Republic of Moldova remittances have become a much-discussed subject, the country ranking among the economies with the highest share of remittances in terms of GDP. What is more, remittances, unlike FDI, external trade and other sources of income, seem to have a significant impact on economic growth. Republic of Moldova is a small open economy vulnerable to external shocks. We will examine the effect of remittances on the balance of trade by creating an econometric model. Am attempt has also been made to capture the positive and negative spillovers that migrants' remittances have on a country's socioeconomic development. Within the research a variety of analytical tools are employed including Granger causality tests, unit root tests, coupled with a structural vector auto regression (SVAR), impulse response function (IRF) analyses and variance decomposition. We find that net trade and remittances are closely associated and follow an almost identical path. Remittances have strong effect on the growth of negative net trade of the Republic of Moldova.
\end{abstract}

Keywords: net trade, remittances, Granger Causality Test, SVAR, variance decomposition, IRF analyses.

JEL: F10, F24.

\section{Introduction}

The definition used by the Republic of Moldova for remittance is the definition from the directive 2007/64/EC of the European Parliament and of

\footnotetext{
${ }^{1}$ Mircea Diavor is PhD student at Academy of Economic Studies of Moldova, Chisinau, Republic of Moldova, https://orcid.org/0000-0002-4041-6356. E-mail: mirceadiavor@gmail.com
} 
the Council of 13 November 2007: "money remittance means a payment service where funds are received from a payer, without any payment accounts being created in the name of the payer or the payee, for the sole purpose of transferring a corresponding amount to a payee or to another payment service provider acting on behalf of the payee, and/or where such funds are received on behalf of and made available to the payee;" (State Chancellery of the government of Republic of Moldova, p.7).

Remittances are a form of non-commercial money transfer that migrants send home to support their families. They have been growing rapidly especially in countries that exporters of labor and represent a large financial inflow to developing countries.

Despite the volume and, in certain circumstances, the critical role that remittances play in many economies across the world, it is very difficult in this field to track and estimating these flows, as well as their influence on home economies. It is extremely difficult to track the true volume of remittances inflows due to the unlawful migration phenomena and the use of different informal channels to transfer money in the home country at cheaper costs. In 2020 the World Bank (WB, 2021) estimated that remittances amounted to a total 646.237 billion dollars (WB, 2021). Despite COVID-19, remittance flows were stable in 2020, declining at a lower rate than predicted. Remittances to low and middle-income countries were officially reported at $\$ 540$ billion in 2020 , barely $1.6 \%$ lower than the amount of $\$ 548$ billion in 2019 , compared to a drop of $4.8 \%$ in 2009 , according to the World Bank. That is far lower than the fall of foreign direct investment (FDI) flows to low and middle-income which fell by over $30 \%$ (WB, 2021). The lower-than-expected fall in remittances might be because sending money throw informal means was not possible during the pandemic restrictions, so remittances were sent mostly throw formal means which can be traced. However, the worldwide pandemic and low oil prices had a severe impact on migrant workers across the area, and remittances to Europe and Central Asia decreased by roughly $9.7 \%$ to $\$ 56$ billion in 2020 (WB, 2021). In comparison to the previous economic crises of 2009 and 2015, when remittances to the area fell by 11 and 15 percent, respectively, the 2020 economic crisis was not unusual (WB, 2021). In 2020 the Republic of Moldova actually recorded an increase in remittances compared to the previous year, 1,486.74 million dollars compared 
to $1,222.89$ million dollars in 2019 (NBM, 2021). This is probably because the majority of money was sent throw formal means.

Remittances can be used to purchase essential consumer items, housing, and children's education and health care in disadvantaged homes. They may offer financing for small companies and entrepreneurial activity in wealthier households. They assist pay for imports and foreign debt payments; in certain nations, banks have used future remittances as collateral to secure abroad funding.

During the financial crisis, remittances from source nations such as the United States and Western Europe proved to be robust. Migrants' wages were impacted by the crisis, but many sought to make up for it by reducing their spending and renting costs. Those who were impacted by the crisis found work in other fields. We will test whether for the Republic of Moldova remittances are countercyclical.

Remittances can also have a detrimental impact on local competitiveness by decreasing projected capital returns. Large inflow of remittances can lead to an appreciation of the real effective exchange rate (REER), we will test whether that holds true for the Republic of Moldova.

The migration issue in Moldova may be described as a departure of a large portion of the country's active population, in particular skilled labor, which has prompted fears regarding the economy's future growth. A rise in remittances can also be associated with a decrease in the labor supply for the home country. A labor shortage implies that remittance also account for a potential decrease in economic output. A rise in remittances can thus be associated with a decrease in the labor supply for the home country.

Remittances appear to alleviate poverty, enhance educational achievement, and lead to better health outcomes. As a result, it's logical that policymakers are becoming more concerned with the quantity of remittances pouring into their nations. Remittances can reduce poverty and inequality in the Republic of Moldova, the latest data from the National Bureau of Statistics of Republic of Moldova (NBS, 2021) shows that remittances in 2020 accounted for on average $12.9 \%$ of total household income, for the rural area it accounted for $16.1 \%$ and for the urban area for 9.4\% (NBS, 2021).

Remittances drive demand, and due to limited domestic manufacturing capacity, imports rise in lockstep with remittances. Remittances have a direct impact on disposable income, impacting savings, investments (such as in 
education and other social services), and consumption. This, in turn, has an impact on tax collections and encourages internal demand. Moldova's production capacity is insufficient to meet rising aggregate demand. The massive rise in imports is mostly due to the surge in aggregate demand. Through their impact on spending, worker remittances have played a key role in recent years in promoting Gross Domestic Product (GDP). Indeed, consumer growth is the primary driver of GDP growth. Remittances from workers have enhanced households' disposable income, allowing them to maintain strong consumption growth rates and thus imports.

As a result, empirical data is required to determine the signs and magnitudes of the various economic implications of remittance movements. An econometric model is constructed to measure the impact of remittances on the net trade of the Republic of Moldova.

The article is structured as follows: Literature review offers review of the prevailing literature, followed by Data and Methodology which provides description of the model, methodology and data sources. Model and Findings presents an in-depth analysis of model and discusses the empirical results. In Conclusions we summarize the findings, limitations of the model and possible direction of future research are suggested.

\section{Literature review}

Remittances are problem analyzed on an international scale, including in post-soviet countries like Armenia.

Armenia diasporas is assumed to be over 7 million, compared to the less than 3 million living in Armenia. That makes it an interesting to study the effect of remittances.

A study conducted on the effect remittances have on household choices in Armenia, concluded that recipients of remittances work less and save more, rather them increase their spending. They also found evidence thar remittance start to decline over time (Grigorian \& Melkonyan, 2011).

Another study concluded that there is a negative relation between remittances and economic growth. The recipients of remittances may not be less inclined to work, viewing remittances as substitution for salary. They also conclude that government may accede to moral hazard problems just like the recipients of remittances. Without receiving large flows of foreign currency, 
the exchange rate would come under strain, so governments may ignore structural problems and imbalances that exist in economy. In case of Republic of Moldova which has a large and persistent trade deficit the inflow of currency hast contributed to the relative stability of the national currency (Chami, Fullenkamp \& Jahjah, 2003).

Analysis on whether remittances have a countercyclical effect in case of Sri Lanka found remittances are procyclical and as such should not be seen a shock absorber (Lueth \& Ruiz-Arranz, 2007).

A research analyzing the economic impact of migration conducted in 2015 found that remittances grew at a faster rate than private capital flows and that the growth rate of remittances has outpaced the growth rate of official development aid (Lazari, Şargu \& Gribincea, 2015).

Another analysis on the remittances flow from 103 Italian provinces to seventy-nine developing countries over the period of 2005 to 2011 found that emittances are adversely linked with the business cycle in recipient nations, and they grow in reaction to external shocks in recipient nations (Bettin, Presbitero \& Spatafora, 2015).

A study using data for El Salvador and Bayesian techniques, concluded that "an increase in remittances ultimately culminates in a rise in household income and consequently an increase in consumption that is biased toward nontradables". As a result of growing non-tradable prices, which are compatible with real exchange rate appreciation, the non-tradable sector expands at the expense of the tradable sector. This is referred to in economics as the Dutch disease, a term that first appear in the Economist in 1977 to describe the downfall of the industrial sector in the Netherlands that occurred after the discovery of the Groningen natural gas field in 1959 (Acosta, Lartey, \& Mandelman, 2009, p.17).

A research conducted in 2013 found that "in Republic of Moldova huge share of negative net export in GDP determines depreciation of national currency and compensate appreciation pressure from remittances inflow". They also found that there is no clear relation between remittances and growth (Stratan, Chistruga, Clipa, Fala \& Septelici, 2013, p.27).

Rising remittances in emerging countries can have a significant spending effect, resulting in a rise in the relative price of non-tradable and real exchange rate appreciation, according to this study. The findings also 
show that a rise in remittances is followed by a resource mobility effect that favors the non-tradable sector at the expense of tradable products (Lartey, Mandelman, \& Acosta, 2008).

A research of the "relationship between workers' remittances and the real exchange rate in 10 developing countries, using Pedroni's panel cointegration tests and FMOLS estimator" was realized. The author obtained data that contradicted the hypothesis of Dutch disease. Remittances from workers have the ability to depreciate the real currency rate in these ten recipient nations, improving their export competitiveness in the world economy (Özcan, 2011, p.1).

The result of researches on relationship between remittances and REER are ambiguous, and should be studies further.

A study conducted using a Vector Error Correction Model (VECM), concluded that in the case of Bangladesh an increase in remittances will cause an increase in inflation. In particular for food price, where a percentage a 15 increase in remittances will lead to the growth of the prices of food by $1.91 \%$ (Roy \& Rahman, 2014).

Another study on remittances and inflation, measured as the Consumer Price Index (CPI), was conducted using a (VECM) in the case of Pakistan. They found that remittances do increase inflation when exchange rate is included in the model (Ghauri, Ahmed, Vveinhardt, Streimikiene \& Qureshi, 2019).

A research using data from Morocco concluded that remittances can provide a stimulant for the recipients to emigrate (van Dalenm Groenewold \& Fokkema, 2005).

A study on the trade balance of Serbia concluded that the large and increasing international trade imbalance of Serbia is clearly funded in part by large remittance inflows (Jovicic \& Mitrovic, 2006).

Another study on the impact of remittances on trade balance, was conducted using a sample 17 countries in the Asia-Pacific region in the period 1980-2015. The author found that remittance inflows have had a negative effect on the trade balance of the countries included in the study (Tung, 2018).

A research concluded that have a positive effect on the economic development of Estonia, Latvia and Lithuania. They also found that "remittances cause GDP growth to 18.3 units and consumption growth to 7.7 units." (Rausser, Strielkowski, Bilan \& Tsevukh, 2018, p.9). 


\section{Data and Methodology}

Despite the volume and, in certain circumstances, the critical role that remittances play in many economies across the world, it is very difficult in this field to track and estimating these flows, as well as their influence on home economies. It is extremely difficult to track the true volume of remittances inflows due to the unlawful migration phenomena and the use of different informal channels to transfer money in the home country at cheaper costs.

The exact value of remittance is hard to estimate, for the purpose of this research our main data source for remittances is the National Bank of Moldova, for other variables the International Monetary Fund (IMF), for the model. For comparative analysis with other countries, we will use data from the World Bank, for analysis of growth in construction sector data from National Bureau of Statistics of Republic of Moldova. We will use quarterly data from 2000Q1 to 2020Q1, avoiding the impact of the pandemic.

A Vector Autoregression (VAR) is a kind of stochastic process model. By allowing for multivariate time series, VAR models extend the singlevariable (univariate) autoregressive model. The Structural Vector Autoregression is a variant of the unconstrained VAR, which is a method for forecasting numerous variables in a system. While we let the data to speak and act for itself in a typical unconstrained VAR, the structural VAR introduces crucial limitations that define rules for how particular variables will behave.

In the model we will take the logs of all variables in order to obtain elasticities, and then take the first difference to ensure the stationarity of variables.

We will use a Structural Vector Autoregression (SVAR) model to capture the relationship between the following variables:

- Net trade- which is calculated as the difference between imports and exports, net trade is negative (imports are bigger than exports). So, when net trade drops the trade balance improves;

- Remittances;

- Imports;

- h_consum- which stands for household consumption;

- CPI- which stands for consumer price index;

- Lending_rate- which stands for the lending rate;

- REER- which stands for Real Effective Exchange Rate; 
- Dummy- We will use a dummy variable as an exogenous variable to reflect the effect of the financial crisis. The dummy variable will take the value of one for the periods 2008Q3-2009Q1.

\section{The model and findings}

Remittances drive demand, and due to limited domestic manufacturing capacity, imports rise in lockstep with remittances. Remittances have a direct impact on disposable income, impacting savings, investments (such as in education and other social services), and consumption. This, in turn, has an impact on tax collections and encourages internal demand. Moldova's production capacity is insufficient to meet rising aggregate demand. The massive rise in imports is mostly due to the surge in aggregate demand. Through their impact on spending, worker remittances have played a key role in recent years in promoting GDP. Indeed, consumer growth is the primary driver of GDP growth. Remittances from workers have enhanced households' disposable income, allowing them to maintain strong consumption growth rates and thus imports.

We will begin our analysis by studying the main destinations of migrants from Republic of Moldova using the latest data (2017) from the World Bank, presented in table 1 (see Appendix, Table 1).

In 2017 in total there were over one million migrants, up from 770.5 thousand in 2010. We are using the latest data available; however, we have to be cautious with interpreting the data. The numbers of migrants in Russia has very likely shrieked, due to the impact of the pandemic on the Russian economy a large proportion of migrants came back and were unable to return due to the decision of the Russian Federation not to allow entry of people unless they have a Russian citizenship.

We will continue our study by analyzing the value of remittances received for Republic of Moldova and a few selected countries with high level of remittances received and have similarities with the Republic of Moldova in geography, size or former membership of USSR, in figure 1.

In nominal term remittances that Moldova receives are not that large, however Moldova is a small economy so we should analyze remittances as a proportion of GDP, in figure 2. 


\section{Figure 1. Remittances for selected countries, 2001-2020}

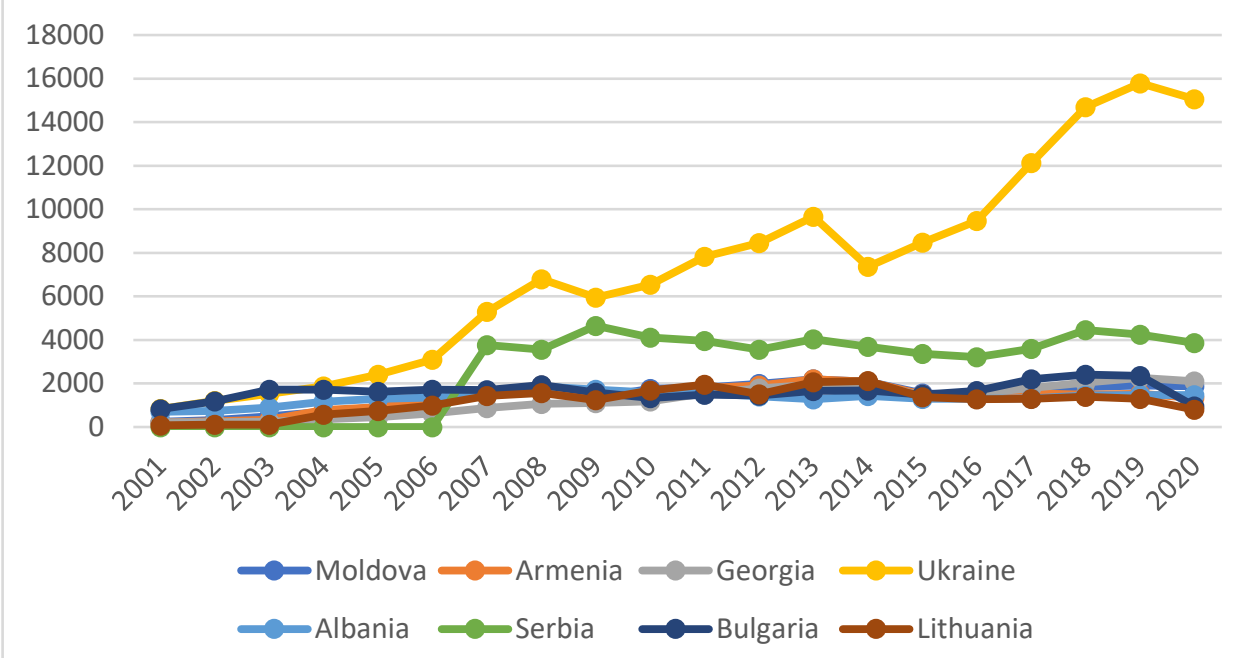

Source: elaborated by author based on data from the WB, available at: https://databank.worldbank.org [visited 22.08.2021]

Republic of Moldova has one the highest remittances to GDP ratio, in the figure above we compare remittances to GDP ratio of Republic of Moldova with similar countries from the region.

Figure 2. Remittances for selected countries as \% of GDP, 2001-2020

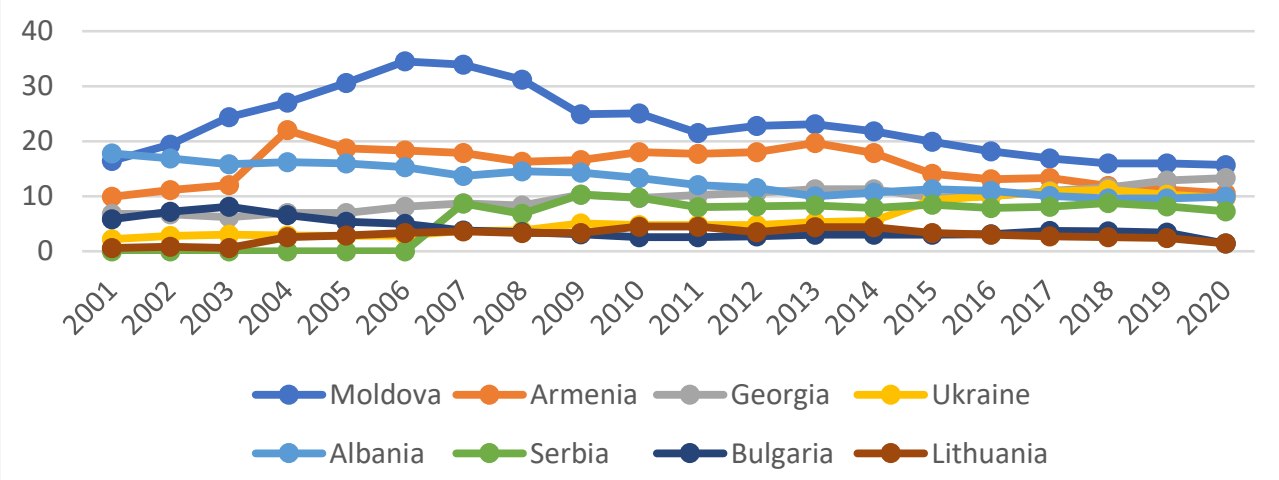

Source: elaborated by author based on data from the World Bank

Once we account for the small size of economy of Republic of Moldova, we see that remittances play a very important role in economic development. In 2006 Republic of Moldova recoded the highest remittances to GDP ratio of $34.5 \%$. Since then, it has dropped to its lowest value in last two decades, in 2020 the ratio was $15.7 \%$, compared to 2001 when it was 
$16.4 \%$. We will analyze whether remittances have a counter cyclical in the case of Republic of Moldova in figure 3. The letter "l" stands for logarithm. Remittances are plotted on the left axis and GDP on the right axis, future figures will be the same.

In case of the Republic of Moldova, remittances where not countercyclical in the 2008 crisis, as shown in figure 2.1. In 2020, remittances appear to be countercyclical, when according to National Bank of Statistics (NBS), GDP fell by $7 \%$ while remittances grow year on year by $21.5 \%$ according to data from the National Bank of Moldova (NBM). As discussed previously this probably because remittances were transfer mostly throw formal means and not because of the countercyclical nature.

\section{Figure 3. Remittances and GDP}

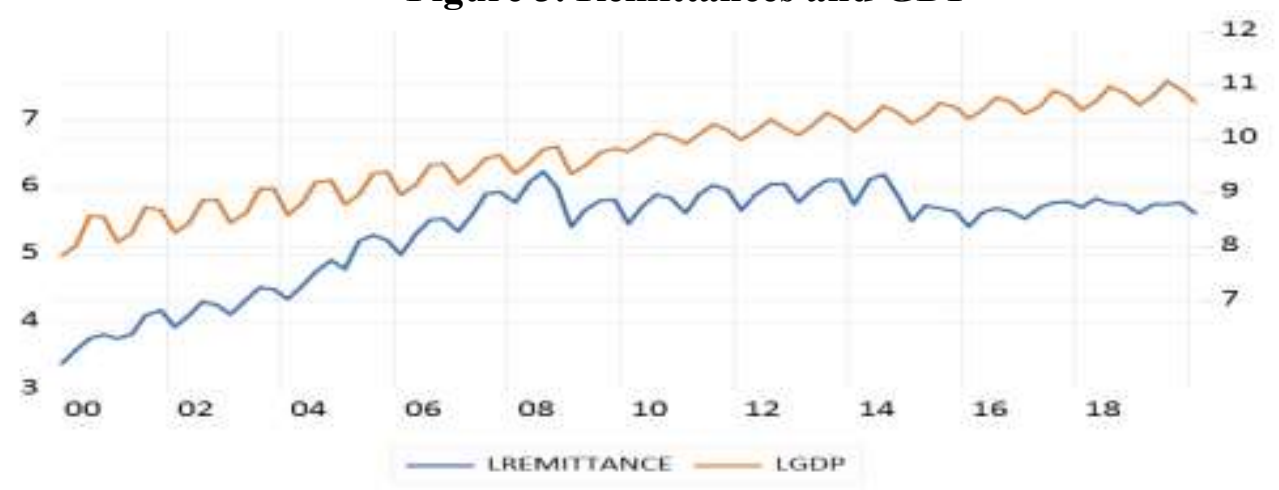

Source: elaborated by author in Eviews 10, based on data of IMF and NBM

One of the symptoms of the Dutch disease is that it increases demand for non-tradable goods, such as the construction sector in figure 1 (Appendix).

According to study on remittances and labor migration in the Republic of Moldova found that the "largest share of migrants' remittances has been invested either in the house/apartment procurement/construction" (Ghencea \& Gudumac, 2004, p.64), which means that some of the effects of the Dutch disease seems to hold true for the Republic of Moldova. The other symptom of Dutch disease which could lead to inflation and the appreciation of the exchange rate, which could reduce the competitiveness of exports, it cannot be said for certain to hold true for the Republic of Moldova, at the tail end there is an increase in the REER but does not appear to be a result of remittances, presented in figure 4 . 


\section{Figure 5. Remittances and REER}

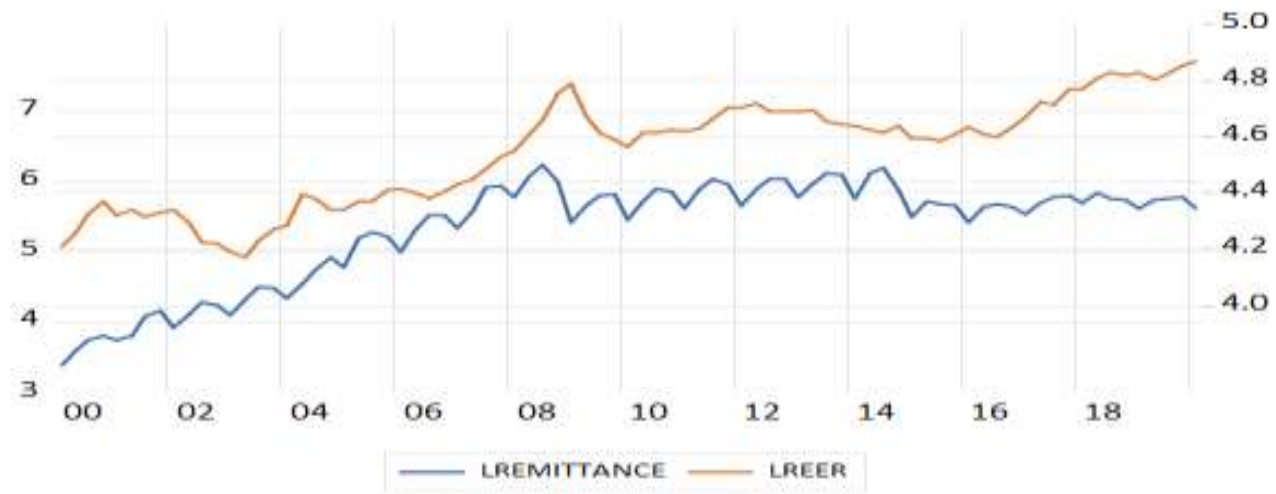

Source: elaborated by author in Eviews 10, based on data of IMF and NBM

Next, we will test whether remittances cause the recipients to emigrate using the Granger Causality Test, the results are presented in Table 1.

Using the Granger Causality Test with 4 lags we reject the null hypothesis for both cases sing the p-values are smaller 0.05 . We can conclude that based on the Granger Causality Test that remittances do cause labor force and that labor force does cause remittances. It is possible that remittance cause the recipients to emigrate which in turn causes an increase remittance.

\section{Table 1. Granger Causality Test for remittances and labor force}

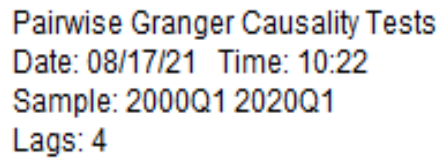

\begin{tabular}{lccc}
\hline \hline Null Hypothesis: & Obs & F-Statistic & Prob. \\
\hline \hline LREMITTANCE does not Granger Cause LLABOR_FORCE & 77 & 3.44356 & 0.0127 \\
LLABOR_FORCE does not Granger Cause LREMITTANCE & & 6.91496 & 0.0001 \\
\hline \hline
\end{tabular}

Source: elaborate by author in Eviews 10, based on data from IMF and NBM

Other studies have shown that remittance can contribute to a negative trade balance, we analyze this in figure 5 .

There is a clear relationship between remittances and net trade (net trade is the negative trade balance). Periods of dips in remittance are connected to 
periods of dip in negative net trade, in other words when remittances decrease the trade balanced improves.

\section{Figure 5. Remittance and Net trade}

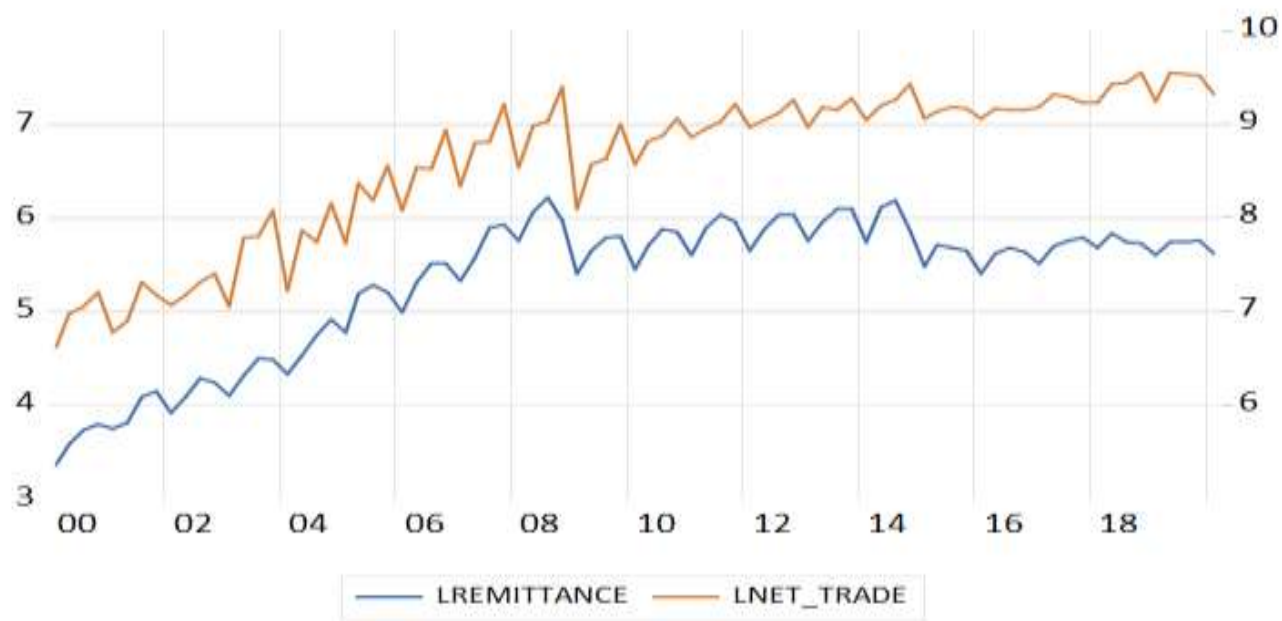

Source: elaborated by author in Eviews 10, based on data of IMF and NBM

In 2017Q1 a dip in remittances had no effect on the negative trade balance, however in 2018Q1 to 2019Q4 we can see a clear v shaped evolution of both variables. The biggest dip was in 2009 Q1, this reflects the effect of the financial crisis. In figure 6 the remittances and household consumption are analyzed.

Like with the negative trade balance, remittances and consumption follow a similar pattern with periods of dips and rises reflected in both variables. The biggest dip was in 2009 Q1, this reflects the effect of the financial crisis. There was a considerable drop in remittances in 2015Q1 that did not seem to effect consumption, perhaps money was sent throw informal means.

Next, we will to create our model by starting with the Unit Root test using Augmented Dickey-Fuller with first difference and an intercept with the Schwarz Info Criterion, to test for the stationarity of variables. 


\section{Figure 6. Remittance and household consumption}

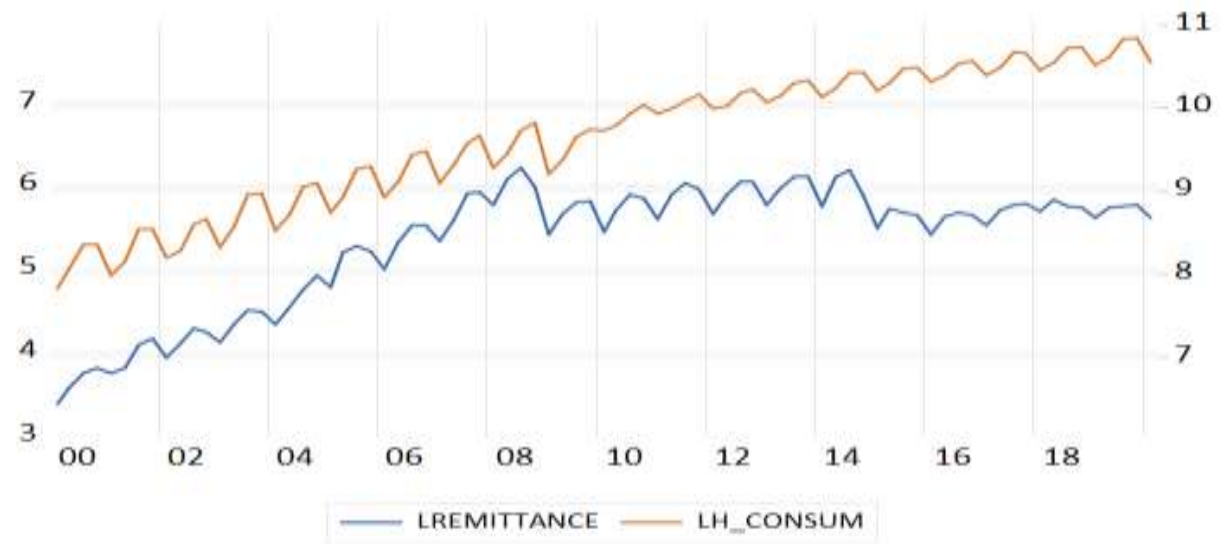

Source: elaborated by author based on information from the IMF and NBM

The result for LNET_TRADE is presented in Table 2 from Appendix.

Test criteria:

1.H0: D(LNET_TRADE) has a unit root and is not stationary;

2.H1: D(LNET_TRADE) has no unit root and is stationary;

$3 . \alpha=5 \%$ or 0.05 ;

4.Prob $=0.0001<0.05$ therefore we reject the $\mathrm{H} 0$;

5.D(LNET_TRADE) does not have a unit root and is stationary.

We perform the same test for all the other variables and conclude there are stationary when taken the log values with first difference.

Next, we have to perform a number of tests to select the correct number of lags. If the lag length is too small than the model will be mis specified, if the lag length is too large than degree of freedom are wasted. The model should be stable and there should be no autocorrelation at the selected lag. The result of the tests are presented in tables 3-5 and figure 2 from Appendix.

The LM Autocorrelation test in the figure indicates that at 4 lags there is no serial autocorrelation problem, so 4 lags would be appropriate. The AR roots graph shows that at 4 lags we are at the limits of the stability of the model. The lag length criteria the SC test suggest 2 lags, AIC suggests 4 . Finally, the residual normality test (Cholesky of covariance method) show there are no problems of normality at 4 lags, the Jarque-Bera p-value of 0.6555 which is higher than 0.05 proves that residuals are multivariate normal. Thus, we will select 4 lags for our model. 
We will next use the Granger causality test. This test allows us to understand which variable Granger cause another. The test result is too large to present as a figure, so we analyze selected variables.

For the Net Trade variable, the Granger Causality Test shows that remittances, consumption, CPI and lending rate all cause negative net trade of Republic of Moldova. It is interesting that the Granger test does not infer that imports cause the negative net trade. Imports are driven by remittances and consumption respectively. In other words, remittances may be more useful at predicting changes in the net trade.

Imports are Granger caused by remittances, consumption, the lending rate and REER.

Household consumption is Granger caused by remittances, the lending rate and REER.

The VAR estimates table is too large to be presented in this paper, but we will discuss the results. We have also estimate individual equations, in total 210 coefficients. As an example, the equation for net trade is presented in figure14 (see appendix).

Table 6 from Appendix shows the equation for net trade. The DurbinWatson coefficient is close to the value of 2, so we do not have problems of autocorrelation. The same is true for all the other equations.

In continuation, we will now proceed with the analysis for the VAR estimation results starting with net trade.

We can see that net trade is strongly endogenous (strong influence) on its own first lag with a T-statistic of -3.519 and p-value of 0.005 , at lag 3 it has a T-statistic of -1.729 and is significant at the $10 \%$ level.

Remittance has a strong influence on the net trade balance at the first lag with a T-statistic of 4.43 and a p-value of 0.000 . It also has a strong influence at the second lag, with a T-statistic of 2.3 and a p-value of 0.217 , but then it dies out.

The CPI at the first two lags is positive and has a T-statistic of 1.44 at lag 1, at lag 2 it has a weak influence on net trade balance. At lag 3 however it has strong negative influence with a T-statistic of -3.2 and p-value of 0.0015 , at lag 4 it has a positive influence lag with a T-statistic of 1.65 and is significant at the $10 \%$ level. 
The REER has a significant and negative influence on negative net trade at the second lag with a T-statistic of -1.95 and p-value of 0.0512 .

Moving to imports remittances have strong and positive influence at the first two lags on imports. At lag 1 the T-statistic is 4.36 and at lag 2 the Tstatistic is 2.29 with p-values of 0.000 and 0.0222 respectively. At lag 3 and particularly lag 4 the remittances are strongly exogenous (have a weak influence) on imports.

Imports strongly influenced by its own first two lags, but not the third and fourth lag. The T-statistics for the first and second lag are -2.59 and -3.14 , with p-values of 0.0098 and 0.0019 .

Household consumption does not have strong influence on imports at the first three lags, but has a strong influence at the fourth lag. At lag 4 the Tstatistic is 2.31 and a p-value of 0.0213 .

The CPI has a strong negative influence on imports at lag 3, with Tstatistic of -2.45 and p-value of 0.0147 .

Imports are strongly influenced by lending rate at lag one and three, a smaller influence at lag four. For lag 1 the T-statistic is 2.48 and the p-value is 0.0136 , at lag three the coefficient is negative with a T-statistic of -2.38 and a p-value of 0.0179 . The fourth lag has a p-value of 0.1143 and could be considered significant at the $10 \%$ level, with a T-statistic of 1.58 .

The REER has a strong negative influence of imports at lag (at 10\% significance level) one and three. The T-statistics are -1.69 and -2.41 , with values of 0.0913 and 0.0162 .

The final variable that we will analyze is household consumption. Household consumption is strongly influenced by remittance at the first lag, with T-statistic of 3.15 and a p-value of 0.0018 . At lags two, three and four remittance is strongly exogenous.

Imports have a significant influence on household consumption at the first lag with a T-statistic -2.520 and p-value of 0.0122 .

Household consumption is strongly influenced by its own second and fourth lag. The T-statistic for the second lag is -4.118 and p-value of 0.000 , at the fourth lag the T-statistic is 2.48 and the p-value of 0.0134 . The CPI at lag 4 has T-statistic of 1.77 and a p-value of 0.0777 , so it is significant at the $10 \%$ level.

The lending rate is strongly endogenous on household consumption at the first three lags. The T-statistic are 1.82, -2.86 and -1.82 and their 
respective p-values $0.0697,0.0045$ and 0.0700 . The second lag is significant at the $5 \%$ level, is also has the highest T-statistic.

Finally, the REER has a strong influence on household consumption at las 2 and 3. The T-statistic are -1.88 and -3.32 with p-values of 0.0608 and 0.0010 respectively.

Next, we will analyze the variance decomposition, which shows the percentage of the error made forecasting a variable aver time due to specific shock. It will tell us how much variability of the dependent variable is explained by its own shocks and how much is explained by shocks in the other variables. We will analyze the variance decomposition for net trade, imports and remittance. The result of the variance decomposition of net trade are presented in the table 2 .

\section{Table 2. Variance decomposition net trade}

\begin{tabular}{|c|c|c|c|c|c|c|c|c|}
\hline \multicolumn{9}{|c|}{ Variance Decomposition of D(LNET_TRADE): } \\
\hline Period & S.E. & D(LNET_T.. & D(LREMITT. & D(LIMPORT) & $\mathrm{D}\left(\mathrm{LH} \_\mathrm{CON} \ldots\right.$ & $\mathrm{D}(\mathrm{LCPI})$ & D(LREER) & D(LLENDI... \\
\hline 1 & 0.114250 & 100.0000 & 0.000000 & 0.000000 & 0.000000 & 0.000000 & 0.000000 & 0.000000 \\
\hline 2 & 0.164082 & 79.28870 & 12.03953 & 0.145979 & 0.398164 & 3.925991 & 0.040133 & 4.161499 \\
\hline 3 & 0.186373 & 69.94848 & 10.64660 & 0.292684 & 0.644561 & 4.678222 & 4.126290 & 9.663167 \\
\hline 4 & 0.203687 & 64.88303 & 9.261735 & 1.759493 & 0.616079 & 11.40928 & 3.473668 & 8.596714 \\
\hline 5 & 0.216817 & 66.28090 & 8.233564 & 1.558696 & 1.307119 & 11.20683 & 3.267477 & 8.145412 \\
\hline 6 & 0.227199 & 66.72446 & 8.063480 & 1.846930 & 1.851134 & 10.34859 & 3.283347 & 7.882061 \\
\hline 7 & 0.234570 & 64.19571 & 7.698215 & 1.732794 & 1.767017 & 13.36313 & 3.236113 & 8.007020 \\
\hline 8 & 0.238484 & 63.85940 & 7.673488 & 1.788741 & 1.731114 & 13.95164 & 3.236005 & 7.759615 \\
\hline 9 & 0.249748 & 61.95432 & 7.026958 & 2.867603 & 4.037228 & 13.50444 & 3.477264 & 7.132185 \\
\hline 10 & 0.256819 & 60.28603 & 6.646790 & 3.559294 & 5.904443 & 12.88500 & 3.400024 & 7.318425 \\
\hline
\end{tabular}

Source: elaborated by author in Eviews 10, based on data of IMF and NBM

For net trade we can see that in first period it is $100 \%$ explained by its own shocks. In second period remittance explains $12 \%$ of changes in net trade, while lending rate $4.16 \%$ and CPI explains 3.9\%. In the third period remittances star decaying representing $10.64 \%$, lending rate plateaus at $9.6 \%$ and CPI grows to $4.67 \%$. We also see that in the third period REER, which for the first two periods did was had not a significant influence on net trade, now explains $4.1 \%$ of the variation in net trade, and continuous to be significant in the following periods. For the fourth period CPI jumps from $4.67 \%$ to $11.4 \%$ and continuous be important in explaining the changes in net 
trade. Household consumption in the fifth period start becoming significant and only reaches significant value in the ninth and tenth period when it explains $5.9 \%$ of the changes in net trade.

Next, we will analyze the variance decomposition of imports in Table 3.

\section{Table 3. Variance decomposition imports}

\begin{tabular}{ccccccccc}
\multicolumn{2}{l}{$\begin{array}{l}\text { Variance Decomposition of D(LIMPORT): } \\
\text { Period }\end{array}$} & S.E. & D(LNET_T... & D(LREMITT... D(LIMPORT) & D(LH_CON... & D(LCPI) & D(LLENDI... & D(LREER) \\
\hline \hline 1 & 0.062718 & 59.35519 & 6.270287 & 34.37452 & 0.000000 & 0.000000 & 0.000000 & 0.000000 \\
2 & 0.081074 & 51.69932 & 9.333837 & 26.67185 & 0.095595 & 1.416446 & 7.957447 & 2.825502 \\
3 & 0.090731 & 48.94005 & 8.040457 & 22.37071 & 3.434246 & 2.790127 & 10.76106 & 3.663345 \\
4 & 0.098854 & 48.81826 & 6.829476 & 19.27006 & 3.425103 & 7.217472 & 9.912204 & 4.527424 \\
5 & 0.108856 & 52.12324 & 6.024841 & 17.29971 & 5.440319 & 6.586503 & 8.235370 & 4.290012 \\
6 & 0.117172 & 54.40464 & 6.319598 & 16.07390 & 5.156128 & 5.914219 & 7.944892 & 4.186626 \\
7 & 0.122341 & 52.41502 & 6.355162 & 14.75570 & 4.870554 & 9.443204 & 8.284394 & 3.875965 \\
8 & 0.125587 & 52.95699 & 6.033826 & 14.07830 & 5.011969 & 9.845418 & 7.862559 & 4.210940 \\
9 & 0.134963 & 51.26437 & 5.620081 & 13.81121 & 8.221586 & 9.753827 & 6.842582 & 4.486339 \\
10 & 0.139261 & 50.46167 & 5.392773 & 14.13501 & 8.996798 & 9.494210 & 7.305591 & 4.213946
\end{tabular}

Source: elaborate by author in Eviews 10, based on data from IMF and NBM

Now we will analyze the decomposition of imports. In the first period net trade explains $59 \%$ of the shocks in importance, since net trade is calculated as the difference of exports and imports. The second variable that explains the variance in imports is remittances. Remittances finance a substantial part of imports. In second period remittances plateau at $9.33 \%$ and star to decay, lending rate explains $7.95 \%$. Consumer and businesses take loans to purchase goods or services, this in turn increases imports. However, household spending only becomes significant in explaining the changes in imports in third period and continuous to be significant. The lending rate plateaus in the third periods at $10.76 \%$ and starts to decay, REER becomes significant at explaining the variation in imports at lag 2 , and continues to be significant at around $4 \%$. CPI becomes significant in the third period at $2.8 \%$ and then jumps in nest period to $7.2 \%$ and continues to be significant in explaining imports.

Finally, we will analyze the effect of shocks to household consumption, in table 4 . In the first period $61.8 \%$ of shocks to the household consumption are explained by its own shocks. Net trade explains $27.59 \%$, remittances explain $6.59 \%$ and imports $3.95 \%$. In the second period imports jumps and plateau at 
$10.56 \%$ and continue to be significant. CPI becomes significant at $2.36 \%$ and in the fourth period explains $8.84 \%$ of the changes in household consumption.

\section{Tabel 4. Variance decomposition Household consumption}

\section{Variance Decomposition of D(LH_CONSUM):}

Period S.E. D(LNET_T... D(LREMITT... D(LIMPORT) D(LH_CON... D(LCPI) D(LLENDI... D(LREER)

\begin{tabular}{ccccccccc}
\hline \hline 1 & 0.051418 & 27.58898 & 6.590820 & 3.952990 & 61.86721 & 0.000000 & 0.000000 & 0.000000 \\
2 & 0.060728 & 28.72463 & 6.847469 & 10.56883 & 45.24154 & 2.360300 & 4.986271 & 1.270968 \\
3 & 0.071887 & 23.51774 & 8.092071 & 7.834790 & 34.92134 & 6.507442 & 15.91770 & 3.208913 \\
4 & 0.079274 & 23.82844 & 6.729842 & 9.209148 & 28.78690 & 8.848083 & 13.45692 & 9.140669 \\
5 & 0.088922 & 20.98243 & 7.142608 & 7.401602 & 34.83522 & 7.361135 & 12.04455 & 10.23245 \\
6 & 0.092733 & 19.75332 & 6.851134 & 8.186720 & 34.15825 & 7.802254 & 11.11290 & 12.13542 \\
7 & 0.099031 & 17.32117 & 7.823931 & 7.337072 & 35.13771 & 10.81107 & 10.11554 & 11.45350 \\
8 & 0.101054 & 18.21094 & 7.775546 & 7.047511 & 34.08698 & 10.47498 & 9.715236 & 12.68880 \\
9 & 0.109184 & 17.33216 & 8.063555 & 6.276555 & 37.86009 & 9.291782 & 8.402958 & 12.77291 \\
10 & 0.111986 & 16.47973 & 8.083718 & 6.877483 & 38.20982 & 9.390148 & 8.454088 & 12.50502
\end{tabular}

Source: elaborated by author in Eviews 10, based on data of IMF and NBM

The lending rate start to become significant in the second period at $4.98 \%$ and then jumps to $15.91 \%$ in the third period. From there it starts to decay, but continuous to be significant in explaining the variation in household consumption. In the third period REER is significant in explaining the variation in household consumption at $3.2 \%$ and then jumps to $9.14 \%$ in the fourth period and continues to remain significant at around $12 \%$.

Next, we proceed with the impulse-response function. Impulseresponse functions allow track the reaction of the variables in our model to a one unit increase in the current value of one of the VAR errors. In plain terms how a unit shock in " $x$ " effects " $y$ ".

We will apply a SVAR with shorth-run impulse response by imposing restrictions on the S-matrix. We will select accumulated responses and 10 periods. For the impulse definition we will use Cholesky decomposition method.

Figure 7 presents impulse-responses of net trade to remittances. In figure 7 the $\mathrm{x}$ axis (bottom) represents periods, in this case quarters. The $y$ axis (left) shows the percentage change. The orange dots are the standard error confidence bands. The confidence intervals are calculated as $+/-2$ standard error confidence bands. The magnitude of the shock is one standard deviation. So, a 
shock in remittances has a positive effect on net trade, net trade is negative, so an increase in net trade is a deterioration of the trade balance.

\section{Figure 7. Impulse-response function of net trade to remittances Accumulated Response of D(LNET_TRADE) to D(LREMITTANCE)}
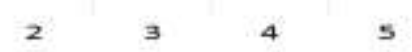

6

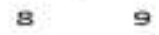

10

Source: elaborated by author in Eviews 10, based on data of IMF and NBM

In second quarter a one standard deviation shock in remittances correspondence to 0.057 increase in the net trade, which when transformed from standard deviation into percentage gives us that a $1 \%$ change in remittances in the second quarter corresponds to $0.73 \%$ change in net trade. The effect is long lasting even after 10 quarters.

In figure 8 we analyze the impulse-responses of net trade to household consumption.

\section{Figure 8. Impulse-response function of net trade to household consumption}

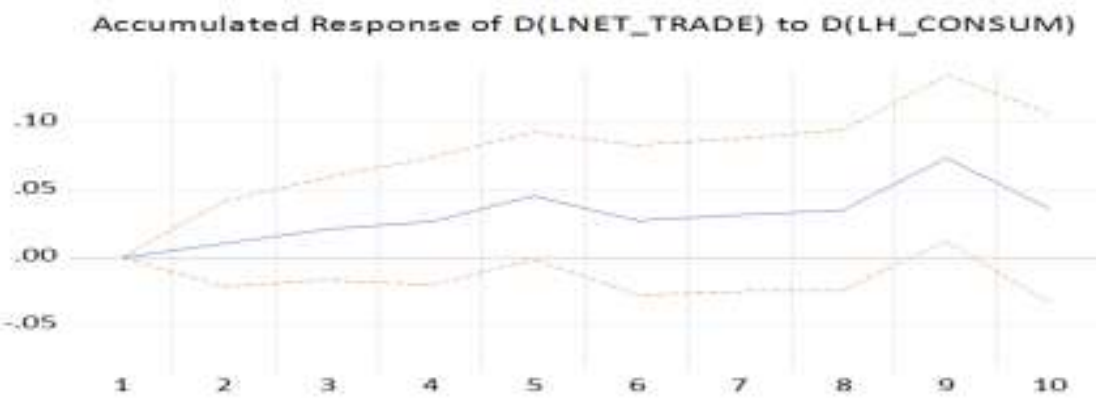

Source: elaborated by author in Eviews 10, based on data of IMF and NBM

Analyzing Figure 9 we can conclude that household consumption has a positive and long-lasting effect on net trade. However, unlike remittances it 
grows gradually then rises in the fifth quarter, after that follows the pattern on gradual growth and a peak in the ninth quarter after which it falls.

In the next figure analyze the impulse-responses of net trade to Consumer price index are analyzed.

\section{Figure 9. Impulse-response function of net trade to Consumer price index \\ Accumulated Response of D(LNET_TRADE) to D(LCPI)}

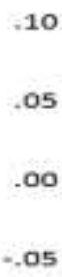

$\begin{array}{ccccccccc}\text { Source: elaborated by author in } & \text { Eviews } & \text { 10, based on data of IMF and NBM }\end{array}$

In figure 9 net trade responds to a one standard deviation shock increasing steadily until the third quarter, after which it plunges to 0 . It is possible that consumers anticipating a rise in prices decide to increase consumption, and thus imports, contributing to an increase in net trade in the first three periods. It however never goes negative, indicating that increases to CPI do not improve the trade balance in the short term. The result of figure 9 show that under short term restrictions consumption remains robust even when prices increase.

Finally, in figure 10 we analyze the impulse-response function of net trade to lending rate. We expect that as a result of an increase in the lending rate consumption should decrease and import should decrease, thus the negative net trade should decrease, but that doesn't happen in the first two quarters. However, in the third quarter that is exactly what happens and it continues until the sixth quarter, is stays negative until the tenth quarter. When comparing the result of figure 9 and 10 we can see that the negative net trade drops in the third period as a result of the increase in lending rate and becomes negative, however net trade drops in the fourth period after an increase in the CPI. 


\section{Figure 10. Impulse-response function of Net Trade to Lending Rate} Accumulated Response of D(LNET_TRADE) to D(LLENDING_RATE)

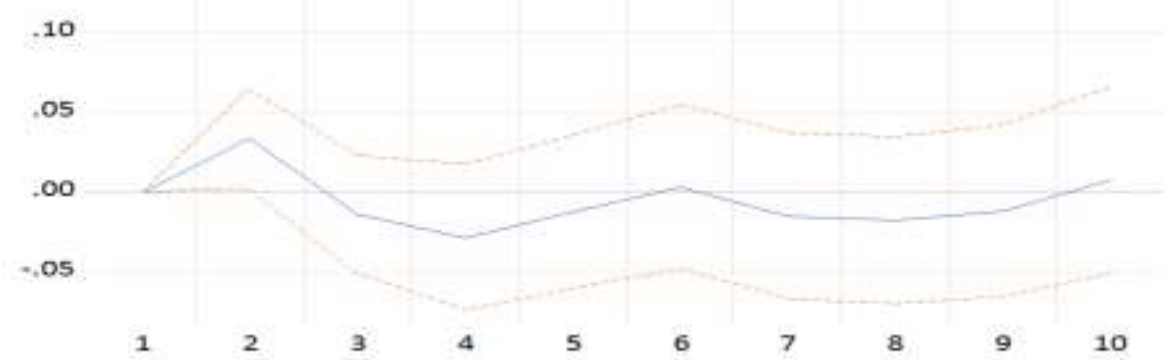

Source: elaborated by author in Eviews 10, based on data of IMF and NBM

This can be explained that after initially taken a loan a period of time is then necessary to pay it back. That could also explain the trend observed.

\section{Conclusions}

We analyze how remittances effect the net trade of Republic of Moldova using a multitude of analytical tolls: Granger Causality Tests, Structural Vector Auto Regression model, Variance Decomposition and Impulse Response Function.

A limitation of the model is that the exact value of remittances is difficult to estimate due the informal channels used by migrants to transfer money to the home country. In the future the dataset may be improved by taking the data for remittances for the year 2020, a year in which due the pandemic restrictions on the movement of people were put in place making it more difficult to transfer throw informal means, and then interpolating the data to the previous years. This however requires proper and substantial explanation for using data that is different from that offered by National Bank of Moldova or other official sources.

Having completed an in-depth analysis of the impact of remittances on the economy of the Republic of Moldova and in particular on the net trade of the Republic of Moldova we can conclude the following:

- Republic of Moldova has a very high remittances to GDP ratio, in 2020 the ratio was $15.7 \%$, constituting a source major vulnerability; 
- A considerable amount of consumption in Republic of Moldova is sustained by remittances;

- Remittances and net trade are closely associated and fallow an almost identical path;

- Remittances do not appear to be counter cyclical in case of Republic of Moldova;

- Based on the Granger Causality Test we can conclude that remittances cause recipient to emigrate, and that a shrinking labor force causes remittances to increase;

- Based on the Granger Causality Test we can conclude that remittances, consumption, CPI and lending rate all cause negative net trade of Republic of Moldova;

- In the short-term remittances may be more useful to predict changes in net trade;

- In the second quarter remittances, CPI and the lending rate explain about $20 \%$ of the variation in net trade;

- The shocks in remittances have the biggest impact on net trade in second quarter, about $12 \%$, after which it decays;

- According to our model remittances have strong and continuous positive impact on net trade, peaking in second quarter;

- In the second quarter a $1 \%$ change in remittances corresponds to $0.73 \%$ change in net trade;

- Consumption has a moderate impact in the short term on net trade;

- In the short-term an increase in CPI does not cause the trade balance to improve;

- An increase in lending rate has cause net trade to decrease, so the trade balance improves.

In future researches the model may be used for forecasting and scenario testing. The model has strong forecast performance with a Theil Inequality Coefficient for Net Trade using static method of forecast of 0.0043 , and 0.017 using dynamic method of forecast. Scenario testing would be particularly useful for testing how a change in one variable would impact the other variables within the model, that would allow policymakers to anticipate and plan ahead for shocks. 


\section{References:}

Acosta, P. A., Lartey, E. K. K., Mandelman, F. S. (2009). Remittances and the Dutch Disease, Working Paper 2007(8a). Federal Reserve Bank of Atlanta. https://www.econstor.eu/bitstream/10419/70606/1/572362153.pdf;

Bettin, G., Presbitero, A. F., \& Spatafora, N.L. (2015). Remittances and Vulnerability in Developing Countries. The World Bank Economic Review, 31(1), 1-23. https://doi.org/10.1093/wber/lhv053;

Chami, R., Fullenkamp, C., \& Jahjah, S. (2003). Are Immigrant Remittances Flows a Source of Capital for Development? IMF Working Paper WP/03/189. https://www.imf.org/external/pubs/ft/wp/2003/wp03189.pdf;

Ghencea, B., \& Gudumac, I. (2004). Labor migration and remittances in the Republic of Moldova. Moldova Microfinance Alliance and Soros Foundation Moldova.http://pdc.ceu.hu/archive/00002327/01/Raport Migration_Remittances_2.pdf;

Ghauri, S. P., Ahmed, R. R., Vveinhardt, J., Streimikiene, D., \& Qureshi, K. S. (2019). The effects of remittances on inflation (CPI and WPI) and exchange rate: A Case of Pakistan. Romanian Journal of Economic Forecasting, XXII (2), 146-16.https://ipe.ro/rjef/rjef2_19/rjef2_2019p146165.pdf;

Grigorian, D. A., \& Melkonyan, T. A. (2011). Destined to Receive: The Impact of Remittances on Household Decisions in Armenia. Review of Development Economics, 15 (1), 139-153. doi.org/10.1111/j.14679361.2010.00598.x;

International Monetary Fund Database, 2021. HTTPs://data.imf.org/

Jovičić, M., \& Mitrović, R. D. (2006). Macroeconomic Analysis of Causes and Effects of Remittances: A Panel Model of the SEE Countries and a Case Study of Serbia. The Vienna Institute for International, Economic Studies Working Papers, 063. https://wiiw.ac.at/macroeconomic-analysisof-causes-and-effects-of-remittances-a-panel-model-of-the-see-countriesand-a-case-study-of-serbia-dlp-3245.pdf;

National Bureau of Statistics of Republic of Moldova, 2021. https://statistica.gov.md/index.php?1=en;

Lartey, E. K. K., Mandelman, F. S., \& Acosta, P. A. (2008). Remittances, exchange rate regimes, and the Dutch disease: A panel data analysis, Working Paper, No. 2008-12. Federal Reserve Bank of Atlanta. https://www.econstor.eu/bitstream/10419/70751/1/572551290.pdf

Lazari, S., Şargu, L., \& Gribincea, A. (2015). The economic impact of refugees. Eastern European Journal for Regional Studies, 1(2), 120126. https://csei.ase.md/journal/files/issue_12/EEJRS_0102_LAZ.pdf. 
Lueth, E., \& Ruiz-Arranz, M. (2007). Are Workers' Remittances a Hedge Against Macroeconomic Shocks?, IMF Working Paper. https://www.imf.org/external/pubs/ft/wp/2007/wp0722.pdf;

National Bank of Moldova Database, 2021. https://www.bnm.md/bdi

Özcan, B. (2011). The Relationship between Workers' Remittances and Real Exchange Rate in Developing Countries. International Research Journal of Finance and Economics, 80, 84-93.

Rausser, G., Strielkowski , W., Bilan, Y., \& Tsevukh, Y. (2018). Migrant remittances and their impact on the economic development of the Baltic States. Geographica Pannonica, 22(3), 165-175. DOI:10.5937/gp2216988

Tung, L. T. 2018). Impact of remittance inflows on trade balance in developing countries. Economics and Sociology Journal of Scientific Papers, 11(4), 80-95. doi:10.14254/2071-789X.2018/11-4/5;

van Dalen, H. P., Groenewold, G., \& Fokkema, T. (2005). The effect of remittances on emigration intentions in Egypt, Morocco, and Turkey. Population Studies, 59(3), 375-392. DOI:10.1080/00324720500249448.

Roy, R., \& Rahman, M. (2014). An Empirical Analysis of Remittance - Inflation Relationship in Bangladesh: Post-Floating Exchange Rate Scenario, Working Paper. Chief Economist's Unit (CEU) Bangladesh Bank.

State Chancellery of the government of Republic of Moldova, Concordance table of the Draft Law on payment service and electronic money. https://cancelaria.gov.md/sites/default/files/tc_pl_serv_de_plata_moneda_ele ctronica.pdf.

Stratan, A., Chistruga, M., Clipa, V., Fala, A., \& Septelici, V. (2013). Development and side effects of remittances in the CIS countries: the case of Republic of Moldova (CARIM-East Research Report 2013/2). Consortium for Applied Research on International Migration. http://dspace.ince.md/jspui/bitstream/123456789/325/3/Development_and_si de_effects_of_remittances_in_the_CIS_countries_the_case_of_Republic_of Moldova.pdf.

World Bank Database, 2021. https://databank.worldbank.org/home.aspx. 
Appendix

Table 1. Migration data of Moldavian citizens

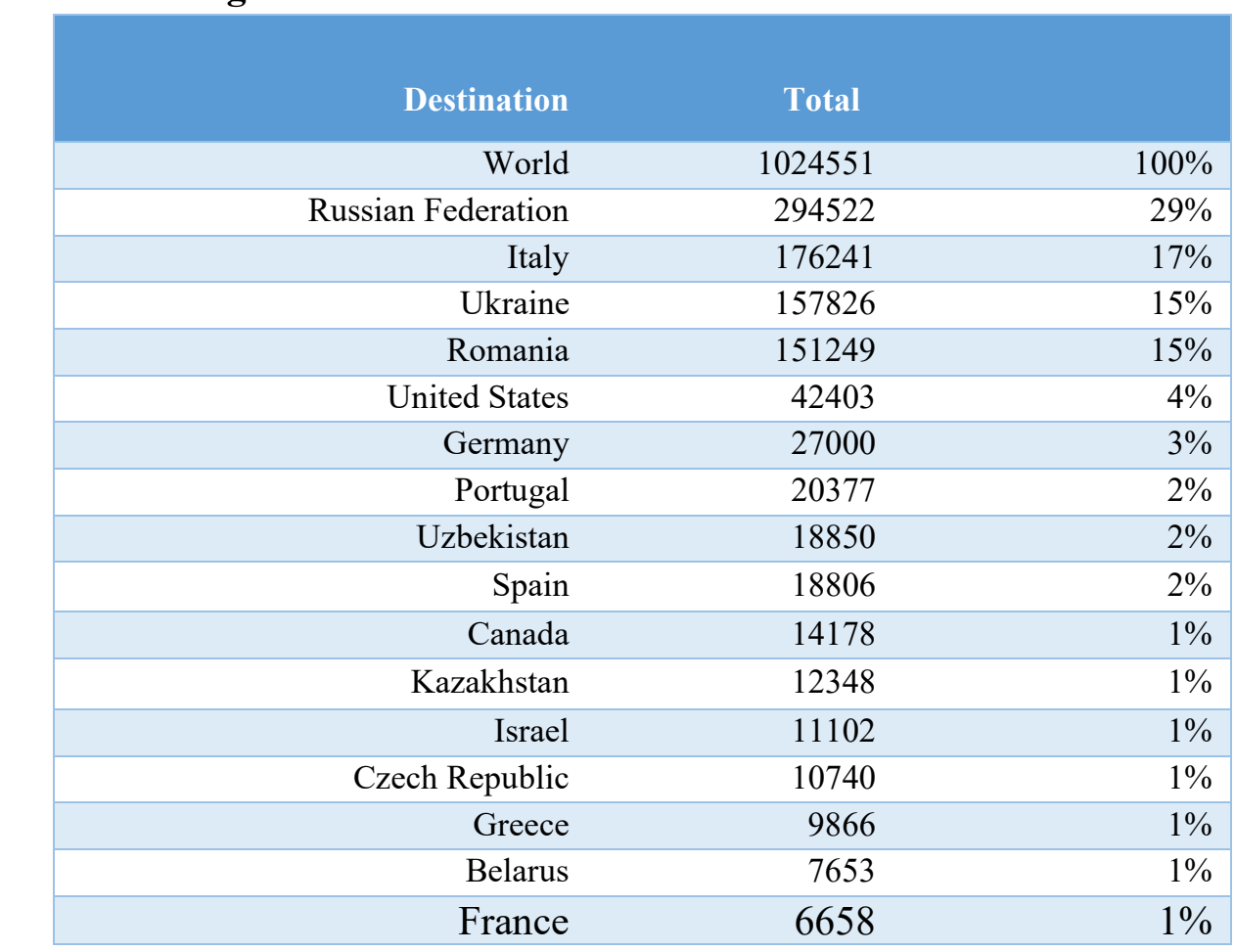

Source: elaborated by author based on data from the WB. https://databank.worldbank.org [visited 22.08.2021]

Figure 1. The trend and value of constructions

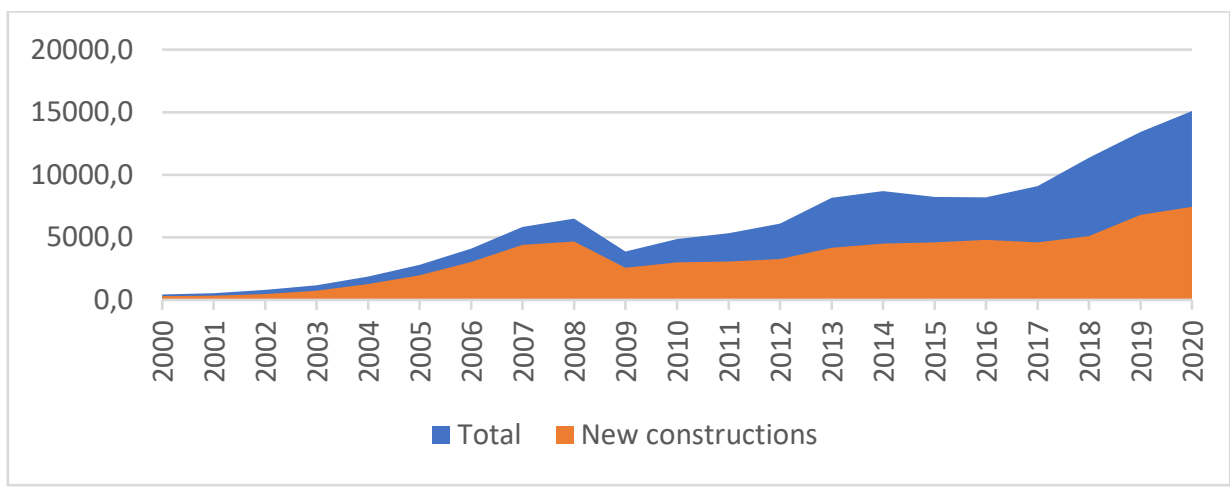

Source: elaborated by author based on data from NBS.

https://statistica.gov.md/index.php 


\section{Table 2. Unit root test for net trade}

Null Hypothesis: D(LNET_TRADE) has a unit root

Exogenous: Constant

Lag Length: 3 (Automatic - based on SIC, maxlag=11)

\begin{tabular}{lccc}
\hline \hline & t-Statistic & Prob.* $^{*}$ \\
\hline \hline Augmented Dickey-Fuller test statistic & -4.821585 & 0.0001 \\
\hline Test critical values: & $1 \%$ level & -3.519050 & \\
& $5 \%$ level & -2.900137 & \\
& $10 \%$ level & -2.587409 & \\
\hline \hline
\end{tabular}

*MacKinnon (1996) one-sided p-values.

Source: elaborated by author in Eviews 10, using data from IMF Test criteria:

6.H0: D(LNET_TRADE) has a unit root and is not stationary;

7.H1: D(LNET_TRADE) has no unit root and is stationary;

$8 . \alpha=5 \%$ or 0.05 ;

9.Prob $=0.0001<0.05$ therefore we reject the $\mathrm{H} 0$;

10. D(LNET_TRADE) does not have a unit root and is stationary.

\section{Table 3. Serial Correlation LM test}

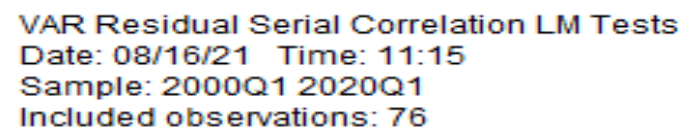

\begin{tabular}{|c|c|c|c|c|c|c|}
\hline Lag & LRE* stat & df & Prob. & Rao F-stat & df & Prob. \\
\hline 1 & 86.09551 & 49 & 0.0008 & 1.942262 & $(49,172.0)$ & 0.0010 \\
\hline 2 & 56.89567 & 49 & 0.2047 & 1.185751 & $(49,172.0)$ & 0.2130 \\
\hline 3 & 53.60402 & 49 & 0.3022 & 1.107344 & $(49,172.0)$ & 0.3118 \\
\hline 4 & 52.85034 & 49 & 0.3277 & 1.089577 & $(49,172.0)$ & 0.3376 \\
\hline 5 & 58.16951 & 49 & 0.1735 & 1.216450 & $(49,172.0)$ & 0.1811 \\
\hline
\end{tabular}

Source: elaborated by author in Eviews 10, based on data of IMF and NBM

\section{Figure 2. AR roots stability}

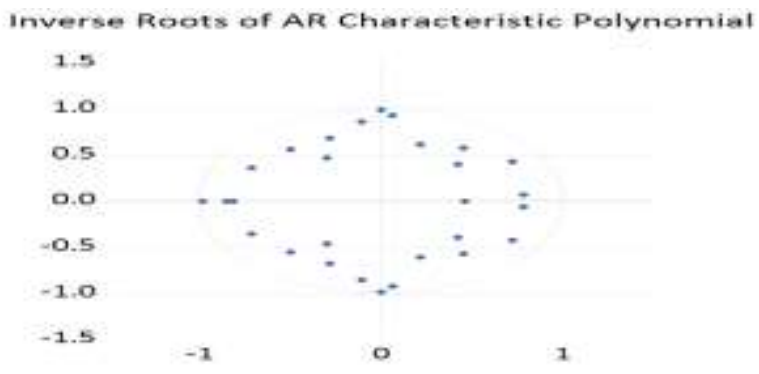

Source: elaborated by author in Eviews 10, based on data of IMF and NBM 
Table 4. Normality test Cholesky of covariance method

\begin{tabular}{cccc} 
Component & Jarque-Bera & df & Prob. \\
\hline \hline 1 & 1.740384 & 2 & 0.4189 \\
2 & 2.164614 & 2 & 0.3388 \\
3 & 0.488083 & 2 & 0.7835 \\
4 & 2.543971 & 2 & 0.2803 \\
5 & 0.417474 & 2 & 0.8116 \\
6 & 0.915996 & 2 & 0.6325 \\
7 & 3.115098 & 2 & 0.2107 \\
\hline \hline Joint & 11.38562 & 14 & 0.6555 \\
\hline \hline
\end{tabular}

Source: elaborated by author in Eviews 10, based on data of IMF and NBM

\section{Table 5. Lag selection criteria}

VAR Lag Order Selection Criteria

Endogenous variables: DLOG(NET_TRADE) DLOG(REMITTANCE) DLOG(IMPORT) ...

Exogenous variables: C DUMMY

Date: 08/16/21 Time: 11:19

Sample: 2000Q1 2020Q1

Included observations: 76

\begin{tabular}{ccccccc}
\hline \hline Lag & LogL & LR & FPE & AIC & SC & HQ \\
\hline \hline 0 & 651.8201 & NA & $1.21 \mathrm{e}-16$ & -16.78474 & -16.35539 & -16.61315 \\
1 & 810.5880 & 279.9328 & $6.79 \mathrm{e}-18$ & -19.67337 & -17.74131 & -18.90123 \\
2 & 942.3256 & 208.0068 & $7.99 \mathrm{e}-19$ & -21.85067 & $-18.41591^{\star}$ & $-20.47798^{\star}$ \\
3 & 998.1105 & 77.80522 & $7.33 \mathrm{e}-19$ & -22.02922 & -17.09175 & -20.05597 \\
4 & 1083.591 & $103.4770^{\star}$ & $3.36 \mathrm{e}-19^{\star}$ & $-22.98925^{\star}$ & -16.54907 & -20.41544 \\
\hline \hline
\end{tabular}

Source: elaborated by author in Eviews 10, based on data from IMF and NBM

\section{Table 6. Equation for Net trade}

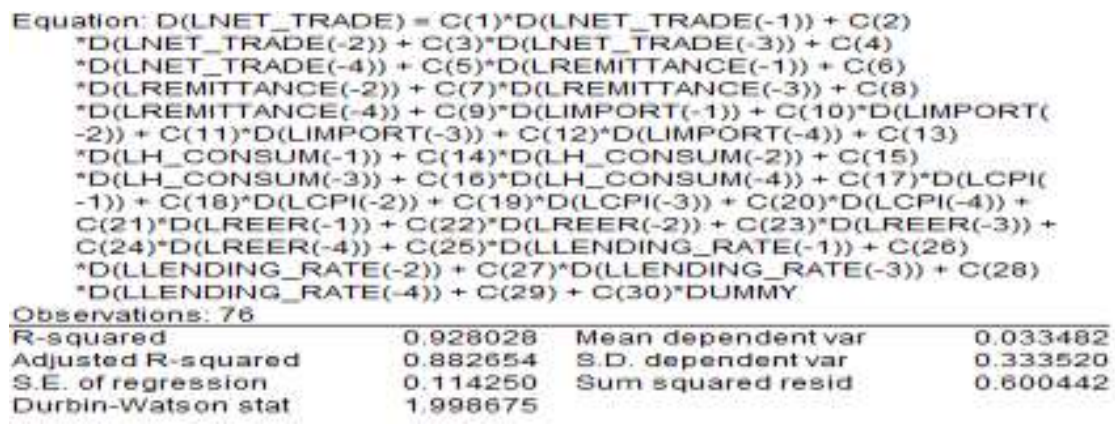

Source: elaborated by author in Eviews 10 